\title{
The allelopathic efficiency of Eruca sativa seed powder in controlling Orobanche crenata infected Vicia faba cultivars
}

\author{
Mahmoud Ahmed Touny El-Dabaa* (D), Salah Abd-Elghany Ahmed, Nadia Khalil Messiha and Rafat Ragheb El-Masry
}

\begin{abstract}
Background: Orobanche crenata (Broomrape) is an obligate root parasitic weed belonging to Orobanchaceae. It causes a great damage to legume crops. Many attempts have been done in order to control this parasitic weed. So, the aim of this work is to study the allelopathic potentiality of Eruca sativa seed powder (Essp) in comparison to the herbicidal effect of Basamid (Dazomet) treatments in controlling Orobanche crenata (O. crenata) and their effect on growth and yield of two Vicia faba cultivars.

Materials/methods: Two pot experiments were conducted in the greenhouse of the National Research Centre, Dokki, Giza, Egypt, in the two successive winter seasons of 2015/2016 and 2016/2017. Treatments were applied by incorporating Essp to the soil at (15, 30, and $45 \mathrm{~g} / \mathrm{kg}$ soil) and Basamid treatments at 0.2 and $0.4 \mathrm{~g} /$ pot.

Results: All Essp concentrations used as well as Basamid treatments minimized to great extent, the number of $O$. crenata tubercles/pot, and the fresh and the dry weight of $O$. crenata tubercles/pot (g) infecting both $V$. faba cultivars at 90 days after sowing (DAS) and at harvest. The best results for controlling $O$. crenata infesting both $V$. faba cultivars were recorded with both $45 \mathrm{~g} / \mathrm{kg}$ soil Essp concentration and $0.4 \mathrm{~g} /$ pot Basamid treatments. On the other side, both $V$. faba cultivars growth as well as yield and yield attributes were significantly increased with all Essp concentrations used and Basamid treatments when compared to their corresponding infected control. Essp at $45 \mathrm{~g} / \mathrm{kg}$ soil and $0.4 \mathrm{~g} /$ pot Basamid treatments gave the highest increases which exceed than their corresponding healthy control.

Conclusion: The presence of the allelochemicals mainly glucosinolates and phenolic compounds in Essp could play an important role, as a natural selective bioherbicide, in controlling the parasitic O. crenata weed infecting $V$. faba cultivars and increasing the yield.
\end{abstract}

Keywords: Allelopathy, Eruca sativa, Glucosinolates, Phenolic content, Vicia faba, Orobanche crenata

\section{Background}

Faba bean (Vicia faba L.) is a major food and feed legume because of its high nutritional value of the seeds. It is considered one of the most important legumes in Egypt. It is also one of the strategic crops due to its income to the farmers, and it is important for soil fertility, human nutrition as a good source of vegetable protein, and industry purposes. Increasing faba bean production and improving yield quality are the major targets to meet the demand of

\footnotetext{
* Correspondence: eldabaam@yahoo.com

Botany Department, Weed Biology and Control, National Research Centre, 33 El Bohouth St. Dokki, P.O. box 12622, Cairo, Egypt
}

the increasing population, since faba bean constitutes a major part of the people's diet (Zeidan, 2002).

Orobanche crenata has been known to threaten legume crops (e.g., faba bean, lentil, pea, and common vetch), since antiquity. The parasitic weed is mainly restricted to the Mediterranean basin, Southern Europe, and Middle East and is an important pest in grain and forage legumes (Rubiales et al., 2009b; Kandil et al., 2015). Due to broomrape infestation, severe yield losses of leguminous plant have been reported depending on the severity of infestation and the planting date (Sauerborn, 1991; Rubiales et al., 2009a; Kandil et al., 2015). Comparing with non-parasitic weeds, the control of 
Orobanche has been proved to be exceptionally difficult in agricultural crops due to its underground location, close association with host plant roots, complex mechanisms of seed dispersal, germination, and longevity (Foy et al., 1989; Linke and Saxena, 1991). So, numbers of strategies for parasitic weed control have been developed including cultural practices and biological and chemical control (Rubiales et al., 2009a; Fernandez-Aparicio et al., 2011).

Using natural or synthetic allelopathic materials has been started as a way to control broomrape (Sauerborn, 1991). Allelopathy is the phenomenon where natural compounds are released from the root, shoot, leaves, or flower of the plant to influence other plants (Rice, 1995), and it may be used to control some weeds. Plants from the Brassicaceae family are characterized by chemical compounds called glucosinolates. The decomposing tissues of these plants release glucosinolates which are then converted to isothiocyanate compounds that are toxic to other plants (Haramoto and Gallandt, 2005; Bangarwa et al., 2011). Particularly, the plants of Brassica genus are known to suppress weeds (Narwal, 1999; Uludag et al., 2006; Uremis et al., 2009).

The aim of the present investigation is to assess the potentiality of Eruca sativa seed powder as one of Brassicaceae family in comparison to the herbicidal effect of Basamid treatment on controlling Orobanche crenata infected two Vicia faba cultivars as well as their effect on the growth and yield of the plant.

\section{Materials and methods}

\section{Experimental procedures}

Two pot experiments were carried out during two successive winter seasons of 2015/2016 and 2016/2017 in the greenhouse of National Research Centre, Dokki, Giza, Egypt. Two Vicia faba L. (faba bean) cultivars (CV. Sakha 1 (a susceptible CV. to Orobanche crenata infection) and Giza 843 (a tolerant CV. to O. crenata infestation) as well as Eruca sativa L. seeds (watercress) were obtained from the Agriculture Research Centre, Giza, while parasitic weed seeds of $O$. crenata (broomrape) were obtained from the weed control section, Ministry of Agric., Giza, Egypt. Clean seeds of E. sativa were ground to fine powder and immediately incorporated to the soil surface before sowing $V$. faba seeds at the rate of 15,30 , and $45 \mathrm{~g} / \mathrm{kg}$ soil. The experiment consisted of seven treatments for each $V$. faba cultivar, including two controls (healthy and infected). Each treatment represented by nine pots $(30-\mathrm{cm}$ diameter) filled with $5-\mathrm{kg}$ Nile clay soil. All treatments, except healthy control, were infected with $O$. crenata seeds $(0.2 \mathrm{~g} /$ pot $)$ at $5 \mathrm{~cm}$ depth from the soil surface. The experiment also includes two herbicidal treatments with Basamid (Dazomet) for comparison with the allelopathic effect of $E$. sativa treatments. Basamid granules (tetrahydro 3,5-dimethyl-2H-1,3,5-thiadiazine-2-thione) were mixed to the soil infected with $O$. crenata at the concentration 0.2 and $0.4 \mathrm{~g} /$ pot 10 days before planting the host seeds. $V$. faba seeds were sown (8 seeds/pot) at $3 \mathrm{~cm}$ from the soil surface. Two weeks later, the $V$. faba plants were thinned to 4 plants/pot. All pots were distributed in a complete randomized design. The normal cultural practices of growing $V$. faba plants especially fertilization and irrigation were done.

\section{Characters studied \\ Weeds}

Three replicates were collected from each treatment at 90 days after sowing (DAS) and at harvest. The number and fresh as well as the dry weight of $O$. crenata tubercles/pot were recorded at the two growth ages.

\section{Vicia faba plants \\ Plant growth}

In both seasons, samples of $V$. faba plants at 60 and 90 DAS were collected from each treatment to determine plant height $(\mathrm{cm})$, number of leaves/plant, number of branches/plant, fresh and dry weight of shoot/plant (g), and fresh and dry weight of root/plant (g).

\section{Yield and yield attributes}

At harvest, samples of $V$. faba plant cultivars were taken from each treatment to determine the number of pods/ pot, pod length $(\mathrm{cm})$, weight of pods/pot $(\mathrm{g})$, number of seeds/pod, weight of seeds/10 pods (g), and weight of 100 seeds (g).

\section{Chemical analysis \\ Total glucosinolates ( $\mu \mathrm{mol} / \mathrm{g} D W$ )}

Total glucosinolates were extracted from dry samples of seed powder of E. sativa. Glucosinolates were measured by determining the liberated glucose which is released during hydrolysis by myrosinase enzyme (Rauchberger et al., 1979). The resulting glucose was determined colorimetrically according to the method defined by Nasirullah and Krishnamurthy (1996).

\section{Total phenol content ( $\mathrm{mg} / \mathrm{g} D W$ )}

Total phenol content of E. sativa seeds was determined colorimetrically using Folin and Ciocalteu phenol reagent according to the method defined by Snell and Snell (1953).

\section{Statistical analysis}

All data were statistically analyzed according to Snedecor and Cochran (1980), and the treatment means were compared by using LSD at $5 \%$ level of probability. 


\section{Results}

\section{Weed growth characters}

The results in Table 1 showed the potential effect of controlling O. crenata in the two Vicia faba cultivars (Sakha 1 and Giza 843) by incorporating different concentrations (15 to $45 \mathrm{~g} / \mathrm{kg}$ soil) of Eruca sativa (Essp) as well as Basamid treatments ( 0.2 and $0.4 \mathrm{~g} / \mathrm{pot})$ to the soil. The data recorded in Table 1 revealed that different Essp concentrations (15 to $45 \mathrm{~g} / \mathrm{kg}$ soil) as well as Basamid treatments $(0.2$ and $0.4 \mathrm{~g} / \mathrm{pot})$ significantly suppressed $O$. crenata infestation and decreased the number, fresh, and dry weight of $O$. crenata tubercles/ pot at the two ages of growth (90 and at harvest) in both $V$. faba cultivars as compared to their corresponding infected controls. The efficiency in controlling O. crenata increased by increasing the applied concentration used. The maximum reduction in number and fresh and dry weight of $O$. crenata was recorded with the highest Essp concentration $(45 \mathrm{~g} / \mathrm{kg}$ soil with Giza, $843 \mathrm{~V}$. faba cultivar) and the higher Basamid treatment $(0.4 \mathrm{~g} /$ pot with Sakha, $1 \mathrm{~V}$. faba cultivar) at the two ages of growth with both $V$. faba cultivars as compared to their corresponding control. The maximum rate of reduction of $O$. crenata tubercles dry weight at harvest was recorded with $45 \mathrm{~g} / \mathrm{kg}$ soil Essp concentration as well as by $0.4 \mathrm{~g} / \mathrm{pot}$
Basamid treatment which reached to 93.50 and $98.23 \%$, respectively, with Sakha $1 \mathrm{~V}$. faba cultivar, while with Giza $843 V$. faba cultivar, the reduction in the same character with the same treatments reached to 99.13 and $98.52 \%$, respectively, as compared to their corresponding control.

O. crenata infestation with Sakha 1 and Giza $843 \mathrm{~V}$. faba cultivars at harvest could be minimized to 89.8 and $99.4 \%$, respectively, by applying $45 \mathrm{~g} / \mathrm{kg}$ soil Essp concentration as compared to their corresponding control as shown in a number of $O$. crenata tubercles/pot (Table 1). It is worthy to mention that at $60 \mathrm{DAS}$, no $O$. crenata tubercle infestation was found in both $V$. faba cultivars.

\section{Vicia faba cultivars' growth}

The results in Tables 2 and 3 illustrated that most growth characters of the two $V$. faba cultivars (Sakha 1 and Giza 843) such as plant height $(\mathrm{cm})$, number of leaves/plant, number of branches/plant, fresh, and dry weight of shoot/plant (g) as well as fresh and dry weight of root/plant (g) at 60 and 90 DAS were significantly increased with all $E$. sativa seed powder concentrations used (15 to $45 \mathrm{~g} / \mathrm{kg}$ soil) as well as Basamid treatments $(0.2$ and $0.4 \mathrm{~g} / \mathrm{pot})$ as compared

Table 1 Effect of different concentrations of Eruca sativa L. seed powder and Basamid herbicide on Orobanche crenata developed in two Vicia faba L. cultivars at 90 days after sowing and at harvest (combined analysis of two seasons)

\begin{tabular}{|c|c|c|c|c|c|c|}
\hline \multirow[t]{2}{*}{ Treatments } & \multicolumn{3}{|c|}{ At 90 days after sowing } & \multicolumn{3}{|l|}{ At harvest } \\
\hline & $\begin{array}{l}\text { No. of } 0 . \text { crenata } \\
\text { tubercles/pot }\end{array}$ & $\begin{array}{l}\text { Fresh wt. of } 0 \text {. } \\
\text { crenata tubercles/ } \\
\text { pot }(\mathrm{g})\end{array}$ & $\begin{array}{l}\text { Dry wt. of } O \text {. crenata } \\
\text { tubercles/pot }(\mathrm{g})\end{array}$ & $\begin{array}{l}\text { No. of O. crenata } \\
\text { tubercles/pot }\end{array}$ & $\begin{array}{l}\text { Fresh wt. of } 0 \text {. } \\
\text { crenata tubercles/ } \\
\text { pot }(\mathrm{g})\end{array}$ & $\begin{array}{l}\text { Dry wt. of } 0 . \\
\text { crenata tubercles/ } \\
\text { pot }(\mathrm{g})\end{array}$ \\
\hline & \multicolumn{6}{|c|}{ Sakha 1} \\
\hline Healthy control & 00.00 & 00.00 & 00.00 & 00.00 & 00.00 & 00.00 \\
\hline Infected control (I) & 59.00 & 52.25 & 7.10 & 64.50 & 61.45 & 10.15 \\
\hline$(\mathrm{l})+$ Eruca sativa $15 \mathrm{~g} / \mathrm{kg}$ soil & 39.02 & 34.62 & 5.62 & 20.28 & 32.61 & 8.29 \\
\hline (I) + Eruca sativa $30 \mathrm{~g} / \mathrm{kg}$ soil & 20.13 & 31.80 & 5.11 & 10.45 & 25.00 & 6.50 \\
\hline (I) + Eruca sativa $45 \mathrm{~g} / \mathrm{kg}$ soil & 7.15 & 16.94 & 4.21 & 6.52 & 3.59 & 0.66 \\
\hline$(\mathrm{I})+$ Basamid $0.2 \mathrm{~g} / \mathrm{pot}$ & 9.00 & 20.65 & 6.12 & 7.26 & 19.39 & 5.10 \\
\hline \multirow[t]{2}{*}{$(\mathrm{I})+$ Basamid $0.4 \mathrm{~g} /$ pot } & 4.00 & 14.75 & 3.83 & 0.57 & 0.86 & 0.18 \\
\hline & \multicolumn{6}{|c|}{ Giza 843} \\
\hline Healthy control & 00.00 & 00.00 & 00.00 & 00.00 & 00.00 & 00.00 \\
\hline Infected control (I) & 50.00 & 36.25 & 5.85 & 54.25 & 46.38 & 8.09 \\
\hline$(\mathrm{l})+$ Eruca sativa $15 \mathrm{~g} / \mathrm{kg}$ soil & 32.45 & 25.13 & 4.16 & 12.79 & 19.92 & 3.71 \\
\hline (I) + Eruca sativa $30 \mathrm{~g} / \mathrm{kg}$ soil & 5.82 & 8.94 & 1.62 & 2.10 & 2.50 & 1.00 \\
\hline (I) + Eruca sativa $45 \mathrm{~g} / \mathrm{kg}$ soil & 1.26 & 1.35 & 0.74 & 0.31 & 0.20 & 0.07 \\
\hline$(\mathrm{I})+$ Basamid $0.2 \mathrm{~g} / \mathrm{pot}$ & 8.00 & 8.75 & 1.15 & 4.55 & 7.76 & 0.99 \\
\hline$(\mathrm{I})+$ Basamid $0.4 \mathrm{~g} / \mathrm{pot}$ & 1.50 & 2.25 & 0.45 & 0.41 & 0.25 & 0.12 \\
\hline LSD at $5 \%$ & 1.84 & 2.61 & 1.09 & 1.78 & 1.93 & 0.77 \\
\hline
\end{tabular}


Table 2 Effect of different concentrations of Eruca sativa L. seed powder and Basamid herbicide on growth parameters of two Vicia faba L. cultivars at 60 days after sowing (combined analysis of two seasons)

\begin{tabular}{|c|c|c|c|c|c|c|c|}
\hline \multirow[t]{2}{*}{ Treatments } & \multicolumn{7}{|c|}{ Growth parameters } \\
\hline & $\begin{array}{l}\text { Plant height } \\
(\mathrm{cm})\end{array}$ & $\begin{array}{l}\text { No. of leaves/ } \\
\text { plant }\end{array}$ & $\begin{array}{l}\text { No. of branches/ } \\
\text { plant }\end{array}$ & $\begin{array}{l}\text { F.W. of shoot/ } \\
\text { plant (g) }\end{array}$ & $\begin{array}{l}\text { F.W. of root/ } \\
\text { plant (g) }\end{array}$ & $\begin{array}{l}\text { D.W. of shoot/ } \\
\text { plant }(\mathrm{g})\end{array}$ & $\begin{array}{l}\text { D.W. of root/ } \\
\text { plant (g) }\end{array}$ \\
\hline & \multicolumn{7}{|c|}{ Sakha 1} \\
\hline Healthy control & 40.50 & 18.96 & 1.80 & 18.63 & 8.55 & 2.75 & 1.26 \\
\hline Infected control (I) & 37.90 & 14.47 & 1.41 & 13.54 & 6.27 & 1.99 & 1.15 \\
\hline (I) + Eruca sativa $15 \mathrm{~g} / \mathrm{kg}$ soil & 38.83 & 17.36 & 1.72 & 16.32 & 6.95 & 2.52 & 1.22 \\
\hline (I) + Eruca sativa $30 \mathrm{~g} / \mathrm{kg}$ soil & 43.52 & 19.55 & 2.00 & 22.42 & 10.25 & 3.56 & 1.41 \\
\hline (I) + Eruca sativa $45 \mathrm{~g} / \mathrm{kg}$ soil & 45.98 & 22.34 & 2.50 & 27.65 & 12.18 & 3.92 & 1.56 \\
\hline (I) + Basamid 0.2 g/pot & 43.62 & 19.21 & 1.86 & 19.95 & 8.96 & 3.24 & 1.29 \\
\hline \multirow[t]{2}{*}{ (I) + Basamid 0.4 g/pot } & 44.38 & 20.82 & 2.15 & 24.55 & 11.54 & 3.71 & 1.43 \\
\hline & \multicolumn{7}{|c|}{ Giza 843} \\
\hline Healthy control & 45.95 & 20.73 & 1.93 & 21.82 & 9.75 & 3.72 & 1.78 \\
\hline Infected control (I) & 41.86 & 15.74 & 1.47 & 15.36 & 7.16 & 2.41 & 1.39 \\
\hline (I) + Eruca sativa $15 \mathrm{~g} / \mathrm{kg}$ soil & 44.19 & 18.22 & 1.80 & 17.83 & 8.09 & 3.13 & 1.49 \\
\hline (I) + Eruca sativa $30 \mathrm{~g} / \mathrm{kg}$ soil & 46.25 & 21.00 & 2.14 & 23.96 & 11.84 & 3.75 & 1.92 \\
\hline (I) + Eruca sativa $45 \mathrm{~g} / \mathrm{kg}$ soil & 48.68 & 24.75 & 2.63 & 33.54 & 17.50 & 4.09 & 2.26 \\
\hline (I) + Basamid 0.2 g/pot & 45.47 & 19.77 & 1.89 & 21.10 & 9.04 & 3.63 & 1.66 \\
\hline (I) + Basamid $0.4 \mathrm{~g} /$ pot & 47.21 & 21.75 & 2.37 & 29.15 & 13.36 & 3.85 & 1.96 \\
\hline LSD at $5 \%$ & 1.82 & 1.88 & 0.22 & 1.30 & 1.18 & 0.33 & 0.18 \\
\hline
\end{tabular}

I infected control

Table 3 Effect of different concentrations of Eruca sativa L. seed powder and Basamid herbicide on growth parameters of two Vicia faba L. cultivars at 90 days after sowing (combined analysis of two seasons)

\begin{tabular}{|c|c|c|c|c|c|c|c|}
\hline \multirow[t]{2}{*}{ Treatments } & \multicolumn{7}{|c|}{ Growth parameters } \\
\hline & $\begin{array}{l}\text { Plant height } \\
(\mathrm{cm})\end{array}$ & $\begin{array}{l}\text { No. of leaves/ } \\
\text { plant }\end{array}$ & $\begin{array}{l}\text { No. of branches/ } \\
\text { plant }\end{array}$ & $\begin{array}{l}\text { F.W. of shoot/ } \\
\text { plant (g) }\end{array}$ & $\begin{array}{l}\text { F.W. of root/ } \\
\text { plant(g) }\end{array}$ & $\begin{array}{l}\text { D.W. of shoot/ } \\
\text { plant (g) }\end{array}$ & $\begin{array}{l}\text { D.W. of root/ } \\
\text { plant (g) }\end{array}$ \\
\hline & \multicolumn{7}{|c|}{ Sakha 1} \\
\hline Healthy control & 58.93 & 20.06 & 1.77 & 21.20 & 3.49 & 3.26 & 1.22 \\
\hline Infected control (I) & 47.62 & 17.43 & 1.59 & 17.09 & 2.89 & 2.66 & 1.04 \\
\hline$(\mathrm{I})+$ Eruca sativa $15 \mathrm{~g} / \mathrm{kg}$ soil & 57.43 & 18.92 & 1.66 & 19.14 & 3.06 & 2.96 & 1.17 \\
\hline$(\mathrm{I})+$ Eruca sativa $30 \mathrm{~g} / \mathrm{kg}$ soil & 60.94 & 22.60 & 1.87 & 35.63 & 3.75 & 5.36 & 1.44 \\
\hline (I) + Eruca sativa $45 \mathrm{~g} / \mathrm{kg}$ soil & 65.00 & 24.64 & 2.64 & 41.11 & 5.31 & 6.64 & 1.82 \\
\hline (I) + Basamid 0.2 g/pot & 59.62 & 20.37 & 1.84 & 23.26 & 3.57 & 3.75 & 1.39 \\
\hline \multirow[t]{2}{*}{ (I) + Basamid 0.4 g/pot } & 61.26 & 23.25 & 2.13 & 37.36 & 4.55 & 6.12 & 1.63 \\
\hline & \multicolumn{7}{|c|}{ Giza 843} \\
\hline Healthy control & 77.10 & 24.36 & 2.55 & 43.44 & 5.83 & 6.32 & 1.63 \\
\hline Infected control (I) & 68.29 & 19.94 & 1.66 & 37.91 & 3.08 & 4.64 & 1.17 \\
\hline (I) + Eruca sativa $15 \mathrm{~g} / \mathrm{kg}$ soil & 70.53 & 21.42 & 1.80 & 40.49 & 3.34 & 5.43 & 1.36 \\
\hline (I) + Eruca sativa $30 \mathrm{~g} / \mathrm{kg}$ soil & 82.51 & 36.90 & 2.33 & 45.26 & 5.42 & 6.54 & 2.27 \\
\hline (I) + Eruca sativa $45 \mathrm{~g} / \mathrm{kg}$ soil & 84.06 & 44.70 & 2.81 & 50.61 & 7.23 & 7.87 & 2.96 \\
\hline (I) + Basamid 0.2 g/pot & 72.85 & 22.99 & 2.16 & 42.37 & 4.47 & 5.53 & 1.44 \\
\hline (I) + Basamid 0.4 g/pot & 80.95 & 35.02 & 2.53 & 49.74 & 6.25 & 7.61 & 2.38 \\
\hline LSD at $5 \%$ & 2.24 & 1.93 & 0.23 & 2.25 & 0.40 & 0.43 & 0.19 \\
\hline
\end{tabular}


to their corresponding infected control. The highest significant increases in different growth parameters of the two $V$. faba cultivars were recorded with both 45 $\mathrm{g} / \mathrm{kg}$ soil of Essp concentration and $0.4 \mathrm{~g} /$ pot Basamid treatment at the two growth ages when compared to the corresponding control in the most growth characters. These treatments not only alleviated the harmful effect of $O$. crenata infestation but also induced significant increases in most growth characters of both $V$. faba cultivars at the two growth ages as compared to their corresponding healthy control. At 90 DAS, Essp at $45 \mathrm{~g} / \mathrm{kg}$ soil concentration and Basamid treatment at $0.4 \mathrm{~g} /$ pot achieved maximum increase in the total dry weight (shoot + root) of (Sakha 1) V. faba cultivar which reached to 88.8 and $72.9 \%$, respectively, over the corresponding healthy control. The second $V$. faba cultivar (Giza 843) recorded increases in the total dry weight with the same treatments and reached to 36.22 and $50.81 \%$, respectively, over the corresponding healthy control.

\section{Vicia faba cultivars' yield}

The results of yield and yield attributes of the two V. faba cultivars (Sakha 1 and Giza 843) such as number of pods/pot, pod length $(\mathrm{cm})$, weight of pods/pot (g), number of seeds/pod, weight of seeds/ 10 pods $(\mathrm{g})$, and weight of 100 seeds $(\mathrm{g})$ recorded in
Table 4 showed that all Essp concentrations (15 to $45 \mathrm{~g} / \mathrm{kg}$ soil) used as well as Basamid treatments $(0.2$ and $0.4 \mathrm{~g} / \mathrm{pot}$ ) significantly increased all yield parameters of the both $V$. faba cultivars as compared to their corresponding infected controls. The best results in the two $V . f a b a$ cultivars yield attributes were recorded with $45 \mathrm{~g} / \mathrm{kg}$ soil Essp and by $0.4 \mathrm{~g} /$ pot Basamid treatment. Both of the previously applied treatments not only alleviated the harmful effect of $O$. crenata infestation but also increased the plant yield over than their corresponding healthy control. The sensitive $V$. faba cultivar (Sakha 1) achieved maximum increase in the weight of seeds/ 10 pods ( $\mathrm{g}$ ) and weight of 100 seeds ( $\mathrm{g}$ ) using the highest Essp concentration $(45 \mathrm{~g} / \mathrm{kg}$ soil), which reached to 54.5 and $45.1 \%$, respectively, while using $0.4 \mathrm{~g} /$ pot Basamid treatment, the increases in the previous yield characters reached to 23.2 and $41.76 \%$, respectively, over their corresponding healthy control. The same trend was obvious with the second $V$. faba cultivar Giza 843, which also recorded maximum increases in the same previous yield characters and showed to 33.59 and $29.19 \%$ with $45 \mathrm{~g} / \mathrm{kg}$ soil Essp concentration, while using $0.4 \mathrm{~g} / \mathrm{pot}$ Basamid treatment, these increases reached to 25.67 and $18.96 \%$, respectively, over their corresponding healthy control.

Table 4 Effect of different concentrations of Eruca sativa L. seed powder and Basamid herbicide on yield and yield attributes of two Vicia faba L. cultivars at harvest (combined analysis of two seasons)

\begin{tabular}{|c|c|c|c|c|c|c|}
\hline \multirow[t]{2}{*}{ Treatments } & \multicolumn{6}{|c|}{ Yield and yield attributes } \\
\hline & $\begin{array}{l}\text { No. of } \\
\text { pods/pot }\end{array}$ & $\begin{array}{l}\text { Pod length } \\
(\mathrm{cm})\end{array}$ & $\begin{array}{l}\text { Wt. of } \\
\text { pods/pot (g) }\end{array}$ & $\begin{array}{l}\text { No. of } \\
\text { seeds/pod }\end{array}$ & $\begin{array}{l}\text { Wt. of seeds/ } \\
10 \text { pods }(\mathrm{g})\end{array}$ & $\begin{array}{l}\text { Wt. of } 100 \\
\text { seeds (g) }\end{array}$ \\
\hline & \multicolumn{6}{|c|}{ Sakha 1} \\
\hline Healthy control & 4.11 & 4.91 & 4.18 & 2.49 & 9.68 & 43.70 \\
\hline Infected control (I) & 2.13 & 3.57 & 1.99 & 1.72 & 4.62 & 22.51 \\
\hline$(\mathrm{I})+$ Eruca sativa $15 \mathrm{~g} / \mathrm{kg}$ soil & 3.00 & 4.25 & 2.81 & 2.35 & 7.10 & 37.00 \\
\hline (I) + Eruca sativa $30 \mathrm{~g} / \mathrm{kg}$ soil & 4.91 & 5.40 & 6.00 & 3.05 & 10.16 & 58.50 \\
\hline (I) + Eruca sativa $45 \mathrm{~g} / \mathrm{kg}$ soil & 6.11 & 6.50 & 7.14 & 3.70 & 14.96 & 63.40 \\
\hline (I) + Basamid $0.2 \mathrm{~g} /$ pot & 4.62 & 5.15 & 4.95 & 2.93 & 9.96 & 48.30 \\
\hline \multirow[t]{2}{*}{$(\mathrm{I})+$ Basamid $0.4 \mathrm{~g} / \mathrm{pot}$} & 5.31 & 5.71 & 6.53 & 3.42 & 11.93 & 61.95 \\
\hline & \multicolumn{6}{|c|}{ Giza 843} \\
\hline Healthy control & 5.30 & 8.19 & 5.38 & 3.52 & 14.26 & 67.50 \\
\hline Infected control (I) & 3.35 & 4.92 & 3.72 & 1.99 & 6.11 & 35.11 \\
\hline$(\mathrm{l})+$ Eruca sativa $15 \mathrm{~g} / \mathrm{kg}$ soil & 4.61 & 7.90 & 5.03 & 3.27 & 12.70 & 55.60 \\
\hline (I) + Eruca sativa $30 \mathrm{~g} / \mathrm{kg}$ soil & 5.80 & 8.70 & 6.09 & 3.86 & 16.93 & 78.10 \\
\hline (l) + Eruca sativa $45 \mathrm{~g} / \mathrm{kg}$ soil & 8.10 & 9.21 & 9.12 & 4.50 & 19.05 & 87.20 \\
\hline$(\mathrm{I})+$ Basamid $0.2 \mathrm{~g} / \mathrm{pot}$ & 4.95 & 7.65 & 5.25 & 3.43 & 13.85 & 62.09 \\
\hline$(\mathrm{I})+$ Basamid $0.4 \mathrm{~g} / \mathrm{pot}$ & 6.52 & 8.96 & 6.96 & 3.99 & 17.92 & 80.30 \\
\hline LSD at $5 \%$ & 0.57 & 0.36 & 0.35 & 0.31 & 0.73 & 2.51 \\
\hline
\end{tabular}

I infected control 
It is worthy to mention that the natural Essp treatment at $45 \mathrm{~g} / \mathrm{kg}$ soil concentration achieved increases exceed than that caused by the herbicidal treatment at $0.4 \mathrm{~g} / \mathrm{pot}$ in both $V$. faba cultivars' yield attributes as compared to their corresponding control (Table 4).

Generally, it is clear from the results recorded in Tables 2, 3, and 4 that the growth parameters as well as the yield and yield attributes of $V$. faba cultivar Giza 843 are better than that of $V$. faba cultivar Sakha 1; these results could be attributed to its partial tolerance to $O$. crenata infestation.

Table 5 clears the amount of total glucosinolates (316.03 $\mu \mathrm{mol} / \mathrm{g}$ dry weight) and total phenolic content (35.62 mg/g dry weight) of Eruca sativa seeds.

\section{Discussion}

The current approaches in agriculture production are to find a suitable biological solution to decrease the harmful effects of the use of herbicides and all other pesticides as well as increasing productivity (Khanh et al., 2005). Allelopathic plants contain many allelopathic compounds (allelochemicals), offer a great possibility to resolve this critical issue, and could be used by different methods to solve this problem (Javaid et al., 2006; Ma et al., 2006; Iqbal et al., 2007). Brassicaceae plant family is considered one of the most important allelopathic plants that contain many allelochemical mainly glucosinolates which are useful and effective to manage different types of weeds in many crops (Biswas et al., 2014; Ahmed et al., 2016; Messiha et al., 2013, 2018).

The results of the present investigation reveal that $E$. sativa seed powder Essp possesses to great extent allelopathic effect in controlling $O$. crenata infesting two $V$. faba cultivars when added to the soil. Incorporating ESSP to the soil at rates from 15 to $45 \mathrm{~g} / \mathrm{kg}$ soil minimized the number of $O$. crenata tubercles as well as their fresh and dry weight especially with the highest concentration $(45 \mathrm{~g} / \mathrm{kg}$ soil). These results were similar to the effect of synthetic herbicide Basamid treatment at $0.4 \mathrm{~g} /$ pot (Table 1), since the mode of action of both is the production of isothiocyanates, which effectively could control the growth of parasitic and non-parasitic weeds (Messiha et al., 1993; Khalaf et al., 1994; Sharara et al., 2011).

It is worthy to mention that the reducing effect of Essp in the weed growth $(O$. crenata) could be attributed to its natural allelochemicals mainly glucosinolates and phenolic compounds (Table 5). Glucosinolates are hydrolyzed by endogenous myrosinase enzyme into many products mainly isothiocyanates (Fenwick et al., 1983) which have different biological function including anticancer, antibacterial, antifungal, antioxidative, allelopathic properties (Traka and Mithen, 2009; Latte et al., 2011) and can also be used as an alternative to synthetic pesticides for pest and disease control (Sarwar and Kirkegaard, 1998) and as bioherbicides for weed control (Messiha et al., 2013, 2018; Ahmed et al., 2014, 2016; El-Masry et al., 2015; El-Rokiek et al., 2017).

The results of the present research reveal that most growth characters and yield attributes of both $V$. faba cultivars significantly increased by different Essp concentrations as well as Basamid treatments Tables 2, 3, and 4 . The best treatments were recorded with both $45 \mathrm{~g} / \mathrm{kg}$ soil Essp and $0.4 \mathrm{~g} /$ pot Basamid. In this connection, it is worthy to mention that improving the growth and consequently increasing the yield of the plant is not only due to the inhibition of weed growth by chemical or biological means that lead to increase the competitive ability of the plant (Abdelhamid and El-Metwally 2008; Ahmed et al., 2012, 2014; El-Rokiek et al., 2012, 2013; El-Masry et al., 2015; Jursik et al., 2015; Seshadri et al., 2015) but also due to the selectivity of the allelochemicals in their action and the plants in their responses (Einhellig, 1995). Allelochemicals which inhibit the growth of some species at certain concentration may stimulate the growth of the same or different species at different concentrations (Ahmed et al., 2012, 2014; Messiha et al., 2013, 2018; Bashen, 2014; El-Masry et al., 2015).

The results of the present study as well as our previous work indicate the possibility of using the allelopathic activity of some Brassicaceae plants' seed powder such as Eruca sativa, Raphanus sativus, Brassica rapa, and Sinapis alba as a selective bioherbicide for controlling annual, perennial, and parasitic weeds accompanied by different economic crop plants (Messiha et al., 2013, 2018; Ahmed et al., 2014, 2016; El-Masry et al., 2015; El-Rokiek et al., 2017).

\section{Conclusion}

Incorporating the seed powder of Eruca sativa to the soil is a powerful and safety method in controlling Orobanche crenata, parasitizing Vicia faba, and also significantly increasing the growth and yield of the plants.

Table 5 Total glucosinolates ( $\mu \mathrm{mol} / \mathrm{g}$ dry weight) and total phenol content (mg/g dry weight) in the seed powder of Eruca sativa

\begin{tabular}{lcc}
\hline Material & Total glucosinolates $(\mu \mathrm{mol} / \mathrm{g}$ dry weight) & Total phenolic content (mg/g dry weight) \\
\hline Eruca sativa seed extract & 316.03 & 35.62 \\
\hline
\end{tabular}




\section{Abbreviations}

CV: Cultivars; DAS: Days after sowing; Essp: Eruca sativa seed powder; $O$. crenata: Orobanche crenata; V. faba: Vicia faba

\section{Acknowledgements}

Thanks are due to the National Research Centre for use of the green house and laboratory facilities

\section{Funding}

The work was self-funded by the authors.

\section{Availability of data and materials}

All data generated or analysed during this study are included in this published article

\section{Authors' contributions}

All authors contributed equally in all parts of this study. All authors read and approved the final manuscript.

\section{Ethics approval and consent to participate}

Not applicable

\section{Consent for publication}

Not applicable

\section{Competing interests}

The authors declare that they have no competing interests.

\section{Publisher's Note}

Springer Nature remains neutral with regard to jurisdictional claims in published maps and institutional affiliations.

\section{Received: 24 November 2018 Accepted: 20 February 2019}

\section{Published online: 28 February 2019}

\section{References}

Abdelhamid MT, El-Metwally IM (2008). Growth, nodulation and yield of soybean and associated weeds as affected by weed management. Planta Daninha, 26 855-863. http://dx.doi.org/https://doi.org/10.1590/S0100-83582008000400017

Ahmed SA, El-Rokiek KG, El-Masry RR, Messiha NK (2014) The efficiency of allelochemicals in the seed powder of Eruca sativa in controlling weeds in Pisum sativum. Middle East J Agric Res 3:757-762

Ahmed SA, Messiha NK, El-Masry RR, El-Rokiek KG (2012) Allelopathic potentiality of the leaf powder of Morus alba and Vitis vinifera on the growth and propagative capacity of purple nutsedge (Cyperus rotundus L.) and maize (Zea mays L.). J. Appl Sci Res 8(8):4744-4751

Ahmed SA, Messiha NK, El-Rokiek KG, Mohamed SA, El-Masry RR (2016) The allelopathic efficiency of two Brassicaceae plant seeds in controlling weeds associating sunflower plants. Res J Pharm Biol Chem Sciences 7(5):158-165

Bangarwa SK, Norsworthy JK, Mattice JD and Gbur EE (2011). Glucosinolate and isothiocyanate production from Brassicaceae cover crops in a plasticulture production system. Weed Sci, 59: 247-254. https://doi.org/https://doi.org/10. 1614/WS-D-10-00137.1

Bashen AA (2014) Morphological and elements constituent effects of allelopathic activity of some medicinal plants extracts on Zea mays. Int J Curr Res Aca Rev 2(4):135-145

Biswas PK, Morshed MM, Ullah MJ, Irin IJ (2014). Allelopathic effect of brassica on weed control and yield of wheat. Bangladesh Agron J, 17(1):73-80. DOl: http://dx.doi.org/https://doi.org/10.3329/baj.v17i1.23679

Einhellig FA (1995). Mechanism of action of allelochemical in allelopathy. In: allelopathy organisms, processes and application. Am. Chem. Soc., Washington, USA, pp.: 96-116

El- Rokiek KG, Ahmed SAA, Messiha NK, Mohamed SA, El-Masry RR (2017) Controlling the grassy weed Avena fatua associating wheat plants with the seed powder of two Brassicaceae plants Brassica rapa and Sinapis alba. Middle East J Agric Res 6(4):1014-1020

El-Masry RR, Messiha NK, El-Rokiek KG, Ahmed SA, Mohamed SA (2015) The allelopathic effect of Eruca sativa. Seed powder on growth and yield of Phaseolus vulgaris and associated weeds. Current Sci. Intern 4:485-490

El-Rokiek KG, Abdelhamid MT, Saad El-Din SA (2013) Physiological response of purslane weed (Portulaca oleracea) and two common beans (Phaseolus vulgaris) recombinant inbred lines to phosphorus fertilizer and bentazon herbicide. J Appl Sci Res 9(4):2743-2749

El-Rokiek KG, El-Nagdi WM, El- Masry RR (2012) Controlling of Portulaca oleracea and Meloidogyne incognita infecting sunflower using leaf extracts of Psidium guava. Arch Phytopathol Plant Protect 45(19):2369-2385

Fenwick GR, Griffiths NM, Heaney RK (1983) Bitterness in Brussels sprouts (Brassica oleracea L. var. gemmifera): the role of glucosinolates and their breakdown products. J Sci Food Agric 34:73-80

Fernandez-Aparicio M, Westwood JH, Rubiales D (2011). Agronomic breeding and biotechnological approaches to parasitic plant management through manipulation of germination stimulant levels in agricultural soils. Botany, 89: 813-826. https://doi.org/https://doi.org/10.1139/b11-075

Foy CL, Jain A, Jacobsohn A (1989). Recent approaches for chemical control of broomrape (Orobanche spp.). Review of Weed Science 4: 123-152

Haramoto ER, Gallandt ER (2005). Brassica cover cropping: 1. Effects on weed and crop establishment. Weed Sci 53: 695-701. https://doi.org/https://doi.org/10. 1614/WS-04-162R.1

lqbal Z, Sarwar M, Jabbar A, Ahmed SA, Nisa M, Sajiad MS, Khan MN, Mufti KA, Yassen M (2007) Direct and indirect anthelmintic effects of condensed tannins in sheep. Vet Parasitol 144:125-131. https://doi.org/10.1016/j.vetpar. 2006.09.035

Javaid A, Anjum T, Bajwa R (2006) Chemical control of Parthenium hysterophorus L. Int J Biol Biotechnol 3:387-390

Jursik M, Soukup J, Holec J, Andr J. Hamouzova K (2015). Efficacy and selectivity of pre- emergent sunflower herbicides under different soil moisture conditions. Plant protect Sci., 51 (4): 214-222. doi: https://doi.org/10.17221/ 82/2014-PPS

Kandil EEE, Kordy AM, Abou Zied AA (2015) New approach for controlling broomrape plants in faba bean. Alexandria Sci Exchange J 36(3):282-291

Khalaf KA, El-Masry RR, Messiha NK (1994). The effect of soil treatment with Basamid (dazomet) on Orobanche crenata and Cuscuta planiflora. Proc $3^{\text {th }}$ Inter Workshop on Orobanche and related Striga Res Amsterdam, 576-579

Khanh TD, Chung MI, Xuan TD, Tawata S (2005). The exploitation of crop allelopathy in sustainable productions. J Agron Crop Sci, 191: 172-184. https://doi.org/https://doi.org/10.1111/j.1439-037X.2005.00172.x

Nasirullah, Krishnamurthy MN (1996) A method for estimating glucosinolates in mustard/rape seeds and cake. J Sci Technol 33(6):498-500

Latte KP, Appel KE, Lampen A (2011) Health benefits and possible risks of broccoli - an overview. Food Chem Toxicol 49:3287-3309. https://doi.org/10. 1016/j.fct.2011.08.019

Linke KH; Saxena MC (1991). Study on viability and longevity of Orobanche seed under laboratory conditions, pp. 110-114. In: proceedings of International Workshop in Orobanche Research (Eds. Wegmann K and Musselman LJ), Tubingen, Germany: Eberhard- Karls- Universitat

Ma Y, Hu H, Berrebi AS, Mothers PH, Agmon A (2006). Distinct subtypes of somatostation-containing neocortical interneurons revealed in transgenic mice. J. Neurosci, 26: 5069-5082. doi: [https://doi.org/10.1523/JNEUROSCI. 0661-06.2006]

Messiha NK, Ahmed SA, El-Rokiek KG, Dawood MG, El-Masry RR (2013) The physiological influence of allelochemicals in two Brassicaceae plant seeds on the growth and propagative capacity of Cyperus rotundus and Zea mays L. World App Sci J 26(9):1142-1149. https://doi.org/10.5829/idosi.wasj.2013.26.09.13548

Messiha NK, El-Dabaa MAT, El-Masry RR, Ahmed SAA (2018) The allelopathic influence of Sinapis alba seed powder (white mustard) on the growth and yield of Vicia faba (faba bean) infected with Orobanche crenata (broomrape). Middle East J Appl Sci 8(2):418-425

Messiha NK, El-Gayar SH, Mohamed SAR (1993) The efficiency of Basamid (Dazomet) in controlling purple nutsedge (Cyperus rotundus L.) in two different Egyptian soils. Egypt J Appl Sci 8(1):369-380

Narwal SS (1999). Allelopathy in weed management. Allelopathy Update, Volume 2, Basic and Applied Aspects (Eds: SS Narwal). 204-254

Rauchberger Y, Mokady S, Cogan (1979). The effect of aqueous leaching of glucosinolates on the nutritive quality of rapeseed meal. J Food Agric, 30: 31-39

Rice $E$ (1995). Biological control of weeds and plant diseases. Advances in Applied Allelopathy Norman, OK: University of Oklahoma Press

Rubiales D, Fernandez-Aparicio M, Haddad A (2009a). Parasitic weeds. The Lentil Botany, Production and Uses. Edited by William Erskine, Fred Muehlbauer, Ashutosh Sarker and Balram Sharma. CAB International, pp. 343-349

Rubiales D, Fernandez-Aparicio M, Wegmann K, Joel DM (2009b) Revisiting strategies for reducing the seed bank of Orobanche and Phelipanche spp. Weed Res 49(1):23-33. https://doi.org/10.1111/j.1365-3180.2009.00742.x 
Sarwar M, Kirkegaard JA (1998) Bio fumigation potential of brassicas. Plant Soil 201:91-101

Sauerborn J (1991) Parasitic flowering plants, ecology and management. Verlag Josef Margraf Scientific Books, Germany 127p

Seshadri SR, Phillip WS, Patrick WG (2015). Broadleaf weed control in sunflower (Helianthus annuus) with preemergence-applied pyroxasulfone with and without sulfentrazone. Agric Sci, 6: 1309-1316. http://dx.doi.org/https://doi. org/10.4236/as.2015.611125

Sharara FA, El-Rokiek KG, Gaweesh SS (2011) Effect of soil fumigation on growth, development, yield of wheat (Triticum aestivum L.) and associated weeds. Int. J Acad Res 3(2):781-786

Snedecor GW, Cochran WG (1980). Statistical methods. $7^{\text {th }}$ Ed. pp.: 507. The lowa State Uni. PRESS, Ames, lowa

Snell FD, Snell CT (1953). Colorimetric methods. Pp.66 Volume 111. Organi, D. Van Nostrand Company, Inc. Toronto, New York, London

Traka M, Mithen R (2009) Glucosinolates, isothiocyanates and human health. Phytochem Rev 8:269-282. https://doi.org/10.1007/s11101-008-9103-7

Uludag A, Uremis I, Arslan M, Gozcu D (2006). Allelopathy studies in weed science in Turkey - a review. J. Plant Dis. Prot. Zeitschrift fur Pflanzenkrankheiten und Pflanzenschutz Sonderheft XX. Pp. 419-426

Uremis I, Arslan M, Uludag A, Sangum M (2009) Allelopathic potentials of residues of 6 Brassica species on Johnsongrass (Sorghum halepense (L.) Pers.). Africa J. Biotechnol 8(15):3497-3501

Zeidan MS (2002) Effect of sowing dates and urea foliar application on growth and seed yield of determinate faba bean (Vicia faba L.) under Egyptian conditions. Egypt J Agron 24:93-102

\section{Submit your manuscript to a SpringerOpen ${ }^{\circ}$ journal and benefit from:}

- Convenient online submission

- Rigorous peer review

- Open access: articles freely available online

High visibility within the field

- Retaining the copyright to your article

Submit your next manuscript at $\boldsymbol{\nabla}$ springeropen.com 